\title{
Determination of Multi-Dimensional Self-Efficacy Beliefs of Prospective Teachers towards Creative Drama Activities
}

\author{
Murat Tezer \\ Assoc. Prof., Near East University, Ataturk Faculty of Education, North Cyprus, Mersin \\ 10, Turkey, 99138, murat.tezer@neu.edu.tr
}

\section{Sebnem Guldal Kan}

Near East University, Ataturk Faculty of Education, North Cyprus, Mersin 10, Turkey, 99138, sebnem.guldal@neu.edu.tr

\section{Cizem Bas}

Near East University, Ataturk Faculty of Education, North Cyprus, Mersin 10, Turkey, 99138, cizem.bas90@gmail.com

The aim of this research is to investigate multi-dimensional self-efficacy beliefs of prospective teachers towards creative drama activities in terms of various variables. The study group consists of 288 prospective teachers attending preschool education and classroom teaching degree undergraduate programs of a private university located in Northern Cyprus in 2017-2018 academic year. The "Multi-Dimensional Self-Efficacy Belief Scale of Prospective teachers towards Creative Drama Activities" that was developed by the researchers was used in the research. The scale was applied to prospective teachers, which was consisting of three dimensions to be "classroom management and communication", the second as "learning-teaching process and evaluation" and the third as "planning" towards creative drama activities. As a result of the analyses that were made, pre-school education and classroom teaching prospective teachers have good multidimensional self-efficacy beliefs towards creative drama activities.

Keywords: creative drama, self-efficacy, prospective teachers, drama activities, preservice teachers

\section{INTRODUCTION}

Albert Bandura (1993) first proposed the self-efficacy conception. This definition of self-efficacy is based on Social Learning Theory of Bandura. According to Bandura, self-efficacy is the self-judgment of an individual on the ability to plan and perform successfully the necessary actions that he/she has to do in order to demonstrate a certain 
performance. In other words, self-efficacy is the belief that individuals can succeed in a certain work. The belief of self-sufficiency helps individuals when a difficulty or misfortune is encountered, and it increases the possibility of coping with such difficulties (Perren, Herrmann, Iljuschin, Frei, Körner \& Sticca, 2017; Petersdotter, Niehoff \& Freund, 2017).

As for self- efficacy of teacher, it consists of the belief of teacher in his/her own ability. Teachers should have self-efficacy belief in order that they could make self-planning, planning, and carrying tasks during teaching. The basis of teachers' self-efficacy grounds on students' success or failure experiences. Accordingly, while student success increases self-efficacy belief level of the teacher, inefficacy of student decreases the self-efficacy belief level of the teacher. Increase in self-efficacy belief level of teacher will bring success and quality in education. It has been determined that the active learning method is effective in increasing the self-efficacy and pedagogical beliefs of pre-service teachers (Sahin-Taskin, 2017). That is why self-efficacy belief levels of teachers have a major importance before they start their profession. As the belief of a novice teacher in his/her profession against own efficacies will increase student success, his/her future professional life success will be influenced positively (Kontaş \& Demir, 2015; Moradkhani, Raygan \& Moein, 2016). In addition, it is known that, some lessons can increase in a way that encourages self-sufficiency of teacher candidates. It is known that self-efficacy has strong effects on teacher effectiveness (Lancaster \& Bain, 2010).

The first step in making a teaching is the planning process. In this phase, the characteristics of the group to be taught should be determined, motivation-enhancing materials should be used by determining the anxieties of the learners, learning environment should be built, and design should be made to implement the applications taking into consideration the classroom interaction. The application phase comes after the planning phase and includes the learning-teaching process. There is a very close relationship between the learning-teaching process and teacher competences. Creation of a positive classroom environment (i.e. the provision of a good classroom management) is necessary for effective teaching to take place and for students to develop a positive attitude towards the classroom (Gökyer and Cihangirlioğlu, 2017). Şahan \& Zöğ (2017) stated that, there is a positive relationship between the teacher competences and the learning-teaching process; also, they mentioned that the teacher competences directly affect the learning-teaching process. Students are expected to access the knowledge and configure it by themselves in the present age. Many techniques and methods have been developed in the field of education to provide this. Evaluation is the final stage of teaching that determines the extent to which teaching objectives are achieved. The evaluation of activities provides information about the efforts, results and achievements of the student teaching process and the effectiveness of the course. Also, it determines the activities of the class have been successful or not (Özkan \& Güvendir, 2016).

Creative drama activities support constructivist approach. It allows students to be more creative and configure the knowledge more easily. The creative drama is one of the modern methods making students more active in the classroom, which improves their creativity and which is generally appropriate for the use of pre-school and primary 
school ages. That is why this method is both used in teacher training in order to increase the quality of education, students' success and provides prospective teachers with knowledge and abilities necessary for conducting their creative drama activities (Gül \& Gücüm, 2015; Pañares \& Cabangon,2016).

The goal of learning through play early in Reggio Emilia was achieved by observing these cheerful and meaningful experiences. Children's own dialogue and drama activities are important here (Pui-Wah, 2010). Taking into consideration teaching process, it draws the attention that the biggest responsibility is of teachers. For this reason, one can be asked that "is it very important in training qualified educators?" In order to train qualified teachers, teacher training should be performed in the direction of certain purposes; training of prospective teachers should be well organized to conduct planning, application and assessment phases. Especially the drama leader that is the teacher should have a certain number of different characteristics as well as qualified teacher characteristics in order that creative drama activities could be successful. Drama leaders should have practical intelligence, developed observation skills, having effective communication and empathy ability and should create a reliable environment that has gained the trust of the group. Teachers who use drama method in education, namely drama leaders should take into consideration the social structure of the class, group rules, communication and roles in the group, and let the emerged product to come into light aesthetically (Çetingöz, 2012; Kontaş \& Demir, 2015; Toivanena, Antikainena \& Ruismäkia, 2012).

In terms of the success of creative drama activities used as a method in education, teachers need to have the characteristics that the drama leader have in order to be able to carry out creative drama activities. For this reason, the teacher candidates who are educated in the education faculties have high self-efficacy belief levels for creative drama activities; it may be a sign that these teachers will be able to continue their creative drama activities effectively when they start their career. Their perceptions and attitudes towards professional qualifications of prospective teachers are of utmost importance for any curriculum. The training of candidate teachers who show a positive attitude towards the teaching profession and who are self-sufficient will have an extremely important effect on the education system and its results (Şahan \& Zöğ, 2017).

Capri, Ozkendir, Ozkurt and Karakus (2012) worked together with prospective teachers in their study and tried to detect the self-efficacy of teachers in physics according to their department, gender and success level perceived in physics. Çetingöz (2012) tried to determine self-efficacy levels of prospective teachers towards using creative drama method in his study. Kılıç and Eyüp (2013) sought to determine self-efficacy beliefs of Turkish Teaching prospective teachers towards creative drama method in their study. Lee, Cawthon and Dawson (2013) tried to investigate in their study the relationship between self-efficacy beliefs of teachers and pedagogical conceptual changes by applying a creative drama based occupational development program to primary school and secondary school teachers. When the literature was reviewed, it was observed that there were studies about the subject, but self-efficacy beliefs of prospective teachers towards using drama method was investigated generally. 
Identification of self-efficacy levels of prospective teachers, arrangement of planning, learning-teaching processes, evaluation, learning-teaching environment of self-efficacy towards using creative drama method, investigating it with communication skills and classroom management dimensions have a big importance for teachers. To train qualified students that keep up with the times and those students could use effectively the methods developing their creativity just like creative drama. In addition, training teachers that can use effectively drama method is important in terms of individuals to keep pace with the times and increasing the quality of education in developing countries like the one where this study was exclusively conducted. The growth of modern individuals helps developing countries to keep pace with the times and get developed. In this way, the study distinguishes from other studies in terms of dimensioning selfefficacies towards drama. The aim of this research is to determine the multi-dimensional self-efficacy beliefs of prospective teachers towards creative drama activities.

\section{METHOD}

It was sought to determine self-efficacy beliefs of prospective teachers and the relationship between these beliefs with several variables by using descriptive survey model in this study. Descriptive researches investigate the coexistence relationship of variables (Kuş, 2012).

\section{Participants}

The participants of the study consist of 300 prospective teachers attending pre-school education and classroom teaching degree undergraduate programs in teaching faculty of a private university located in Northern Cyprus in 2017-2018 academic year. As the study group of the research was determined on voluntary basis, 300 students were contacted under the scope of the research, but inaccurate and incomplete measurement tools were eliminated after the measurement tools were controlled and the data obtained from 288 prospective teachers was used in the research.

Among the participant there were: $80.6 \%$ females, $19.4 \%$ males; according to the department, $60.1 \%$ pre-school prospective teachers while $39.9 \%$ classroom prospective teachers; according to class levels, $42.7 \%$ first level while $28.8 \%$ secondary level, $13.9 \%$ third level and $14.6 \%$ fourth level; according to age range, $38.9 \%$ between the ages $17-19$ while $42 \%$ between $20-22,11.1 \%$ between $22-24,4.5 \%$ between $24-26$ and $3.5 \%$ between 26 and above. Taking into consideration the distribution of prospective teachers towards application frequency of creative drama, the proportions of prospective teachers applying creative drama application were; $42 \%$ never, $30.9 \% 1$ or 2 times, $12.2 \% 2$ or 4 times and $14.9 \% 4$ times and more. Taking into consideration the distributions of prospective teachers according to meeting for the first time with creative drama, the proportions were; $13.2 \%$ met in the primary school, $9 \%$ in the secondary school, $33 \%$ met at high school, $18,8 \%$ met at the university and $26 \%$ never met creative drama.

\section{Data Collection Tool}

Before the development of the multi-dimensional self-efficacy beliefs of prospective teachers towards creative drama activities scale, a demographic information form was 
used to obtain detailed information such as gender, department, age, application frequency of creative drama and the place to meet with creative drama for the first time. As the aim of the research is to investigate multi-dimensional self-efficacy beliefs of prospective teachers towards creative drama activities, a measurement tool should be used in the study. When the items of scale are created for this purpose, 20 prospective teachers receiving education in related department of faculty of education were asked to write a composition comprising their feelings, thoughts and behaviours on self-efficacy towards creative drama. Forty-five items were transcribed as a result of content analysis that was made by compositions and literature review for creative drama activities.

Language specialist investigated multi-dimensional self-efficacy beliefs measurement of prospective teachers towards creative drama activities prepared in this way. The opinions of five lecturers working in university, giving drama lesson were consulted for the scope and face validity of the scale. Experts suggest that five item should be taken out of the scale. The trial form of data collection tool, which is developed to determine multi-dimensional self-efficacy beliefs of prospective teachers towards creative drama activities, has taken its final shape by making the necessary amendments in the direction of the specialists. It is suggested to make item number at least two times by taking into consideration the factor analysis of the size of study group (Kline, 1994). The data collection tool trial form prepared for conducting a valid and reliable analysis of data collection tool was applied to 120 prospective teachers as preliminary trial group. 5point Likert type scale was preferred for the answers to be given in items in the research.

Arithmetic mean, standard deviation and item-total correlations of each item were calculated on the data obtained from prospective teachers mentioned in preliminary trial study in order to determine the items to form the scale. It is based on the criterion that total item correlation coefficient is above .30 in selection of the items to be included in the scale. When item analysis results that are carried out to evaluate the distinctiveness of materials on the scale are evaluated, it can be seen that total item correlations vary from .65 to .86 . It was observed on the basis of preliminary trial study results that the items were comprehensible, and some items needed change of expression. The necessary changes were done and data collection tool was given the final shape.

\section{Application}

Before the scale taking its final shape upon being applied to the preliminary trial group was applied, a brochure explaining the creative drama activities was prepared. Before the application, it was asked for permission of the dean of faculty of education, the head of department of both pre-school teaching and classroom teaching departments were contacted and supplied with information regarding the application and questionnaire, and they were asked to apply it to pre-school teaching and classroom teaching. The questionnaires were applied to volunteer prospective teachers.

\section{Data Analysis}

Before the analysis, Kolmogorov-Smirnov normality test was applied so as to determine whether data distribution realized in normal distribution or not. As a result of Kolmogorov-Smirnov test, it was stated that data did not realize in normal distribution 
( $p>$.05). For this reason, Spearman correlation test was benefited in order to determine the relationship between the factors as a nonparametric test. Frequency and percentage values were calculated to classify the data. Arithmetic average was calculated in order to determine the average of the scores taken. The standard deviation was calculated in order to determine the distance of values in the distribution to the arithmetic mean.

In all statistical studies conducted, the level of significance was accepted to be $p<0.05$ and the data obtained from the survey were coded in the range of 1-5 and transferred to computer environment. The following ranges were taken into consideration when evaluating the arithmetic mean (M) and standard deviation (Sd) of data obtained accordingly with the scale used in the research (Table 1).

Table 1

Scale Ranges

\begin{tabular}{clc}
\hline Weight Given & Options & Limits \\
\hline 1 & I strongly disagree & $1.00-1.80$ \\
2 & I disagree & $1.81-2.60$ \\
3 & I am not sure & $2.61-3.40$ \\
4 & I agree & $3.41-4.20$ \\
5 & I totally agree & $4.21-5.00$ \\
\hline
\end{tabular}

\section{FINDINGS}

The questionnaire "Multi-Dimensional Self-Efficacy Belief Scale of Prospective teachers towards Creative Drama Activities" that was developed by the researchers was used in the research as data collection tool. The questionnaire consists of two sections. There is demographic information in the first section, while there are 5-point Likert type expressions consisting of 40 items intended for determining multidimensional selfefficacy beliefs of prospective teachers to creative drama activities in the second section. The total item correlation of each item was calculated. It is required that in the selection of the items in the scale, the coefficient of total item correlation is above 0.30. So, 5 more items were removed from the scale that have total item correlation is below 0.20 . Factor analysis was carried out in order to examine the construct validity of the questionnaire. Kaiser-Meyer-Olkin (KMO) and Bartlett's tests were first used in order to determine the compliance of data to factor analysis (Table 2).

The lower limit of KMO value is .50. That KMO value is lower than .50 means that data set will not be factored. However, that KMO value is .972 in this study shows that the sample size is appropriate for factor analysis. It was stated that chi-square value which is obtained as a result of Bartlett's test is significant $\left(\mathrm{X}^{2}=9500.303 ; \mathrm{df}=.780 \mathrm{p}<0.05\right)$. The Scree Plot was examined in order to determine factor number that will set forth the relationships between items in less amount and most effective way (Karagöz and Kösterlioğlu, 2008). The Scree Plot obtained for the measurement of determining MultiDimensional Self-Efficacy Beliefs of Prospective teachers towards Creative Drama Activities can be seen in Figure 1. Cronbach Alpha reliability coefficient that was conducted for 35 items remaining after five more items were removed during validity and reliability analyses of the scale was found to be .95 . 
Büyüköztürk (2007) states that Scree Plot is obtained by the combination of eigenvalues of the substances, that is why the declines (break points) that could be seen in the graphic will give the number of factors. It can be understood that the components having decreased in the graphic in Figure 1 are the factors 1 and 2, and the graphic has a horizontal appearance as of the factor number 3. Accordingly, it was observed that significant factor number included in the scale is three.

Table 2

Compliance of Data to Factor Analysis

KMO and Bartlett's Test

Kaiser-Meyer-Olkin Measure of Sampling Adequacy.

Bartlett's Test of Sphericity

Approx. Chi-Square

.973

df $\quad .595$

Sig.

.000

Later on, Varimax rotation technique was applied and it was stated that eigenvalues of scale were gathered in three factors greater than 1 . Variance values of each of the three factors detected and total their impact on total variance value (cumulative variance) can be seen in Table 3 .

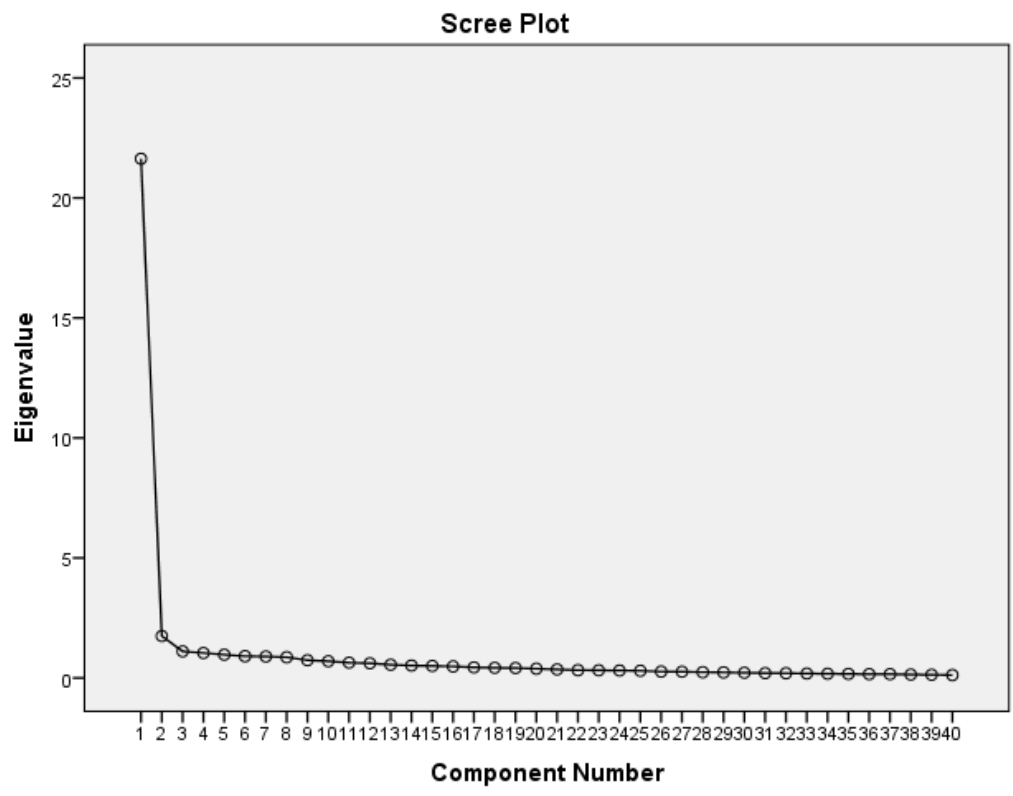

Figure 1

Scree Plot of the Scale 
Table 3

Factor Analysis Results

\begin{tabular}{|c|c|c|c|c|c|c|c|c|c|}
\hline \multirow[b]{2}{*}{ 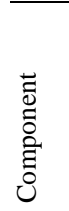 } & \multicolumn{3}{|c|}{ Initial Eigenvalues } & \multicolumn{3}{|c|}{$\begin{array}{c}\text { Extraction Sums of Squared } \\
\text { Loadings }\end{array}$} & \multicolumn{3}{|c|}{$\begin{array}{c}\text { Rotation Sums of Squared } \\
\text { Loadings }\end{array}$} \\
\hline & 胥 & 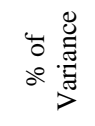 & 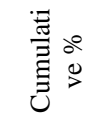 & 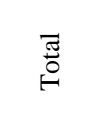 & 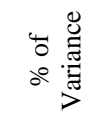 & 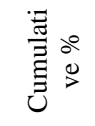 & $\stackrel{\pi}{0}$ & 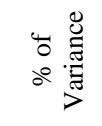 & 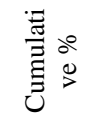 \\
\hline 1 & 20.390 & 58.258 & 58.258 & 20.390 & 58.258 & 58.258 & 9.325 & 26.643 & 26.643 \\
\hline 2 & 1.721 & 4.918 & 63.176 & 1.721 & 4.918 & 63.176 & 8.960 & 25.601 & 52.243 \\
\hline 3 & 1.080 & 3.087 & 66.263 & 1.080 & 3.087 & 66.263 & 4.907 & 14.019 & 66.263 \\
\hline 4 & .928 & 2.651 & 68.914 & & & & & & \\
\hline 5 & .837 & 2.390 & 71.304 & & & & & & \\
\hline 6 & .708 & 2.023 & 73.326 & & & & & & \\
\hline 7 & .647 & 1.850 & 75.176 & & & & & & \\
\hline 8 & .594 & 1.697 & 76.873 & & & & & & \\
\hline 9 & .560 & 1.599 & 78.472 & & & & & & \\
\hline 10 & .515 & 1.472 & 79.944 & & & & & & \\
\hline 11 & .502 & 1.435 & 81.379 & & & & & & \\
\hline 12 & .481 & 1.374 & 82.753 & & & & & & \\
\hline 13 & .450 & 1.285 & 84.038 & & & & & & \\
\hline 14 & .420 & 1.201 & 85.240 & & & & & & \\
\hline 15 & .407 & 1.163 & 86.402 & & & & & & \\
\hline 16 & .384 & 1.097 & 87.499 & & & & & & \\
\hline 17 & .364 & 1.039 & 88.538 & & & & & & \\
\hline 18 & .337 & .963 & 89.501 & & & & & & \\
\hline 19 & .323 & .921 & 90.422 & & & & & & \\
\hline$\vdots$ & $\vdots$ & $\vdots$ & $\vdots$ & & & & & & \\
\hline$\vdots$ & $\vdots$ & $\vdots$ & $\vdots$ & & & & & & \\
\hline$\vdots$ & $\vdots$ & $\vdots$ & $\vdots$ & & & & & & \\
\hline 34 & .139 & .398 & 99.633 & & & & & & \\
\hline 35 & .128 & .367 & 100.000 & & & & & & \\
\hline
\end{tabular}

Extraction Method: Principal Component Analysis

As it can be seen in Table 3, the percentage of variance description of the first factor is 58.258 , while variance description of the second factor is 4.918 and variance description of the third factor is 3.087. The total variance explained with help of three factors was stated to be 66.263 . That total variance ratio has a value between $40 \%$ and $60 \%$ or above in the studies conducted in social sciences refers to the difficulty of factor structure (Tavşanc1l, 2002). This situation demonstrates that total variance ratio of the scale has a sufficient value. They are gathered under three factors after Varimax rotation process. Variance percentages regarding three factors obtained after Varimax rotation process: It is $26.64 \%$ for the first factor, $25.60 \%$ for the second factor, and $11.02 \%$ for the third factor. Rotated factor load values belonging to the scale after Varimax rotation process can be seen in Table 4. In order to determine multidimensional self-efficacy beliefs of prospective teachers towards creative drama activities; 15 items in the first dimension were named as "classroom management and communication", 14 items in the second dimension as "learning and teaching environment and evaluation" and 6 items in the third dimension as "planning". 
Table 4

$\underline{\text { Rotated Component Matrix }}$

\begin{tabular}{ll}
\hline Items & Rotat \\
\cline { 2 - 2 } & Factor \\
\hline I am talented in respect of directing the students for productive activities during & .732 \\
activities. & .734 \\
I believe that I will let students love the course through the activities. & .719 \\
I feel to be qualified in creating a cooperative environment during activities. & .711 \\
I am talented in encouraging the students during activities. & .690 \\
I feel to be sufficient in obeying the predetermined classroom rules during & .681 \\
activities. & .650 \\
I feel to be qualified in directing students to the activities appealing to their & \\
abilities and interest during activities. & .696 \\
I can solve the problems when I encounter unwanted behaviours during & \\
activities without interrupting the class. & .696 \\
I feel to be qualified in creating a democratic classroom environment during & .676 \\
activities. & .638 \\
I believe that I can use I language during activities. & .586 \\
I believe I can feel empathy with the counter person during activities. \\
I believe I can create an effective listening environment during activities. \\
I feel to be sufficient when establishing effective eye contact during activities. \\
I use my language effectively during activities. \\
I prepare learning environment where activities will be realized to meet \\
students' needs.
\end{tabular}

students' needs.

I believe that I could decide on learning environment where activities will be $\quad .586$ carried out appropriately with the activities planned.

I think that I could ensure the subjects studied after activities to be highlighted. $\quad .713$

I let students evaluate themselves after the activities.

I believe to have a grasp of providing possibilities for my students to produce $\quad .629$

their own interpretations during activities.

I believe that I could make my students carry out an evaluation after the

activities.

I believe that I could carry out the discussion-evaluation phase of creative .641

drama after the activities.

I let students draw conclusions from their own experiences after the activities. $\quad .632$

I believe that I could ensure the students to evaluate their friends after the $\quad .581$

activities.

I believe that I can support the students to develop their problem solving $\quad .687$

abilities through the activities.

I believe that I could carry out the preparation-warm up phase of activities.

I believe that I could carry out the preparation-warm up phase of activities

I believe that I could guide students during activities.

I can ensure students to develop critical thinking abilities through activities.

I believe that I could effectively use drama techniques like playing a role,

dramatization, improvisation, and pantomime during activities.

I feel to be qualified in evaluating creative drama activities.

I feel to be sufficient in taking into consideration individual differences of

students while planning activities.

I believe that I could plan the content of activities.

I believe that I can determine the objectives of activities.

I believe that I could plan the activities to support development of students.

I think that I could select the proper materials to use in the activities.

I believe to have a grasp of techniques as well as the method I will use in the 
When factor load values of scale items are investigated, there are 15 items under the first factor, and factor loads of items change between .552 and .734 . There are 14 items under the second factor, and factor loads of items change between .533 and .713 . There are six items under the third factor, and factor loads of items change between .528 and .775. First of these factor components is named "classroom management and communication", the second as "learningteaching process and evaluation" and the third as "planning".

\section{Findings About Multidimensional Self-Efficacy Belief of Prospective Teachers}

It was ascertained that self-efficacy belief levels of prospective teachers is in "I agree" level $(\mathrm{M}=3.98, \mathrm{Sd}=0.848)$ for "classroom management and communication" subdimension, "I agree" level $(\mathrm{M}=3.82, \mathrm{Sd}=0.821)$ for "learning and teaching environment and evaluation" which is the second dimension, and $(\mathrm{M}=3.88, \mathrm{Sd}=0.892)$ for "planning" which is the third dimension. It was observed that self-efficacy beliefs of prospective teachers is in $(\mathrm{M}=3.69, \mathrm{Sd}=0.763)$ "I agree" level in general. The prospective teachers from preschool teaching department have little higher average value $(M=3.82, \mathrm{Sd}=0.740)$ than classroom teaching department $(\mathrm{M}=3.94, \mathrm{Sd}=0.840)$. Also, the female prospective teachers have higher average value $(\mathrm{M}=3.93, \mathrm{Sd}=0.805)$ than males $(\mathrm{M}=3.77, \mathrm{Sd}=0.786)$ but generally their beliefs in "I agree level". Accordingly, it can be said that self-efficacy belief levels of prospective teachers are good.

Table 5

Spearman Correlation Results according to the Relationship between the Factors belonging to the Scale

\begin{tabular}{lllll}
\hline & $\begin{array}{l}\text { Classroom } \\
\text { Management and Environment } \\
\text { Communication }\end{array}$ & $\begin{array}{l}\text { Learning and Teaching } \\
\text { and Evaluation }\end{array}$ & Planning & Grand Total \\
\hline $\begin{array}{l}\text { Classroom Management } \\
\text { and Communication }\end{array}$ & 1,000 & $.740^{* *}$ & $.697^{* *}$ & $.870^{* *}$ \\
$\begin{array}{l}\text { Learning and Teaching } \\
\begin{array}{l}\text { Environment and Evaluation } \\
\text { Planning }\end{array}\end{array}$ & 1,000 & $.783^{* *}$ & $.916^{* *}$ \\
Grand Total & & 1,000 & $.920^{* *}$ \\
\hline
\end{tabular}

**.Correlation is significant at the 0.01 level (2-tailed).

Spearman Correlation results are given in Table 5 regarding the relationship between the factors belonging to the scale. According to this; there seems to be a moderate significant positive relationship between "classroom management and communication" factor and "planning" factor $(\mathrm{r}=.697, \mathrm{p}=.00)$. It is clear that there is a highly positive significant relationship between "classroom management and communication" factor and "learning and teaching environment and evaluation" ( $\mathrm{r}=.740, \mathrm{p}=.00)$, and "grand total" $(\mathrm{r}=.870, \mathrm{p}=.00)$ factor. There was found a highly positive significant relationship between "learning and teaching environment and evaluation" and "classroom management and communication" factor $(r=.740, p=.00)$, "planning" $(r=.783$, $\mathrm{p}=.00)$ and "grand total" $(\mathrm{r}=.870, \mathrm{p}=.00)$ factors. While there was found a moderate positive significant relationship between "planning" and "classroom management and communication" factors, there was found a highly positive significant relationship between "planning" factor and "learning and teaching environment and evaluation" $(\mathrm{r}=.783, \mathrm{p}=.00)$ and "grand total" $(\mathrm{r}=.920$, $\mathrm{p}=.00$ ) factors. There was found a highly positive significant relationship between "grand total" 
factor and "classroom management and communication" factor $(\mathrm{r}=.870, \mathrm{p}=.00)$, "arranging learning and teaching environment and evaluation" $(\mathrm{r}=.916, \mathrm{p}=.00)$ and "planning" $(\mathrm{r}=.920$, $\mathrm{p}=.00$ ) factors.

\section{DISCUSSION AND CONCLUSION}

As a result of the research, multi-dimensional self-efficacy beliefs of prospective teachers towards creative drama activities scale was developed. The dimensions of the scale are "classroom management and communication", "learning and teaching environment and evaluation" "planning". In the past studies the use of drama and integration of drama into the lessons in primary education discussed (Arieli, 2007; Ormanci \& Ören, 2010). After these studies, in the literature, self-efficacy beliefs towards creative drama activities subject was criticized and scales were developed (Akyön, 2011; Almaz, İşeri \& Ünal, 2014; Can \& Cantürk-Günhan, 2009; Karadağ, Korkmaz, Çalişkan \& Yüksel, 2008; Tanriseven, 2013). The multi-dimensional selfefficacy beliefs of prospective teachers towards creative drama activities scale have some differences from the scales developed before. It has less dimensions and, less items than the others have and has no negative items. In addition, it contains items for planning the lesson, learning and teaching environment. The high correlation between the dimensions "classroom management and communication", "learning and teaching environment and evaluation" "planning" showed that the dimension are not distinct phenomenon.

It was found that near the half of the prospective teachers apply creative drama but more than the half of them met with the creative up to high school. In addition, there are one fourth of the prospective teachers that never met with the creative drama.

Pre-school teaching and classroom teaching department prospective teachers have good self-efficacy belief levels on applying creative drama activities. According to the gender, females have better multidimensional self-efficacy beliefs towards creative drama activities but both males and females have good self-efficacy. Similar results found by Almaz, İşeri, \& Ünal (2014). Accordingly, when trainings oriented to use creative drama methods in license programs of pre-school teaching and classroom teaching reach their objectives, these trainings may increase the belief of prospective teachers that they could use creative drama activities in an effective way. Çetingöz (2012) discovered in his study that preschool education prospective teachers have good self-efficacy levels towards using creative drama activities. In a similar study, Kılıç and Eyüp (2013) ascertained that selfefficacy perceptions of Turkish Language prospective teachers towards using creative drama method are on "I reasonably agree" level. Ulaş, Sevim and Tan (2012) found in their study that Turkish Language prospective teachers developed positive attitudes against creative drama courses. McLennan, Mcliveen and Perera (2017) found out in their study that increasing pre-service self-efficacy of prospective teachers would increase accordingly the adaptation to the profession and career optimism of prospective teachers. The results of this study too support the idea that the creative drama courses and programs that prospective teacher stake during their undergraduate degree increases their self-efficacy beliefs towards applying creative drama activities. 


\section{RECOMMENDATION}

Taking into consideration the results of this study, the following suggestions could be made. Self-efficacy researches on gender basis should be carried out. Creative drama courses that are arranged as one semester in classroom teaching programs of education faculties could be arranged as courses given more than a semester and the number of these courses could be reached to a sufficient level. The number of courses towards creative drama and their kinds should be increased in education faculties of universities and the necessary studies should be carried out in order to generalize it. In addition, application frequency in drama courses could be increased and so, the knowledge and abilities of prospective teachers could be supported. Prospective teachers could be better directed in creative drama through activities like seminar, course and workshops outside classes. Self-efficacy studies towards creative drama could be promoted by receiving opinions of prospective teachers. Furthermore, different conclusions could be made related to self-efficacy beliefs of prospective teachers by conducting different qualitative researches.

\section{REFERENCES}

Almaz, G., İșeri, K., \& Ünal, E. (2014). Öğretmen adaylarının yaratıcı drama yöntemini kullanmaya yönelik özyeterlik algılarının incelenmesi. International Journal of Languages' Education and Teaching, 2(3), 48-65.

Akyol, Y. (2011). Okul öncesi eğitim kurumlarında görev yapan öğretmenlerin drama yöntemi yeterliliklerinin değerlendirilmesi. Masters Thesis. Ahi Evran University, social Sciences Institute, June, Kırşehir. https://tez.yok.gov.tr/ulusaltezmerkezi/tarama.jsf,

Arieli, B. B. (2007). The integration of creative drama into science teaching (Doctoral dissertation, Kansas State University).

Bandura, A. (1993). Perceived self-efficacy in cognitive development and functioning. Educational Psychologist, 28 (2), 117-148.

Büyüköztürk, Ş. (2017). Sosyal bilimler için veri analizi el kitabı. Pegem Atıf İndeksi, $1-213$.

Can, B., \& Cantürk-Günhan, B. (2009). Yaratıcı drama yöntemini kullanmaya yönelik özyeterlik ölçeği. E-Journal of New World Sciences Academy (NEWWSA), 4(1), 34-43.

Capri, B., Ozkendir, O. M., Ozkurt B., \& Karakus, F. (2012). Investigation of preservice teacher's attitudes towards physics lesson and self-efficacy beliefs according to their gender, departments and perceived success in physics. Procedia - Social and Behavioral Sciences, 47, 1034 - 1039.

Çetingöz, D. (2012). Pre-school prospective teachers' self-efficacy levels on using the creative drama method. H.U. Journal of Education, 43, 131-142. 
Gökyer, N., \& Cihangiroglu, N. (2017). Ogretmen adaylarının sınıf yonetimi dersine yönelik tutumlarının belirlenmesi. International Journal Of Eurasia Social Sciences, $8(30)$.

Gül, E., \& Gücüm, E.B. (2015). Creative drama applications as complementary for constructivist approaches for science courses: Teacher and Student's Evaluations. Procedia - Social and Behavioral Sciences, 174, 2043 - 2050.

Karadağ, E., Korkmaz, T., Çalişkan, N., \& Yüksel, S. (2008). Drama lideri olarak öğretmen ve eğitimsel drama uygulama yeterliği ölçeği: geçerlik ve güvenirlik analizleri. Gazi Üniversitesi Gazi Ĕgitim Fakültesi Dergisi, 28(2).

Karagöz, Y., \& Kösterelioğlu, İ. (2008). İletişim becerileri değerlendirme ölçeğinin faktör analizi metodu ile geliştirilmesi. Dumlupınar University Social Sciences Journal, 21, 81-98.

Kılıç, K.L., \& Eyüp, B. (2013). Türkçe öğretmeni adaylarının yaratıcı drama yöntemini kullanmaya yönelik öz yeterlik algıları. Adlyaman University Social Sciences Institute Journal, 6(11), 799-821).

Kline, P. (1994). An easy guide to factor analysis. New York: Routledge.

Kontaş, M., Demir, M. (2015). The effect of pedagogical formation courses upon the professional self-efficacy perception of pre-service teachers. Procedia - Social and Behavioral Sciences 174, 1643 - 1649.

Kuş, E. (2012). Nicel nitel araştırma teknikleri. Ankara: Anı Publishing.

Lancaster, J., \& Bain, A. (2010). The design of pre-service inclusive education courses and their effects on self-efficacy: A comparative study. Asia-Pacific Journal of Teacher Education, 38(2), 117-128.

McLennan, B., McIlveen, P., \& Perera, H.N. (2017). Pre-service teacher' self-efficacy mediates the relationship between career adaptability and career optimism. Teaching and Teacher Education, 63, 176-185.

Moradkhani, S., Raygan, A., \& Moein, M. S. (2017). Iranian EFL teachers' reflective practices and self-efficacy: Exploring Possible Relationships. System 65, 1-14.

Pañares, A. A., \& Cabangon, M. G. S. (2016). Drama-in-schools in the Philippines. Research in Drama Education: The Journal of Applied Theatre and Performance, 21(1), 13-16.

Ormanci, Ü., \& Ören, F. S. (2010). Classroom teacher candidates' opinions related to using drama in primary school: An Example of Demirci Faculty of Education. Egitim Bilimleri Fakultesi Dergisi, 43(1), 165.

Özkan, Y., Ö., \& Güvendir, M., A. (2016). Öğretmen adaylarının ölçme ve değerlendirme dersine yönelik algılarının metaforlar yoluyla belirlenmesi. Dumlupınar Üniverstesi Sosyal Bilimler Dergisi, 47. 
Perren, S., Herrmann, S., Iljuschin, I., Frei, D., Körner, C., \& Sticca, F. (2017). Childcentred educational practice in different early education settings: associations with professionals' attitudes, self-efficacy, and professional background. Early Childhood Research, 38, 137-148.

Petersdotter, L., Niehoff, E., Philipp \& Freund, A. (2017). International experience makes a difference: effects of studying abroad on students' self-efficacy. Personality and Individual Differences, 107, 174-178.

Pui-Wah, D. C. (2010). Exploring the tactfulness of implementing play in the classroom: A Hong Kong experience. Asia-Pacific Journal of Teacher Education, 38(1), 69-82.

Sahin-Taskin, C. (2017). Effects of active learning environments supported with selfand peer assessment on pre-service teachers' pedagogical and self-efficacy beliefs. AsiaPacific Journal of Teacher Education, 1-20.

Sarigoz, I, H. (2012). ELT methodology and learners meet in techniques: A lesson planning perspective for teacher trainees. The Journal of Language and Linguistic Studies, 8 (1), 96-109.

Şahan, H. H., \& Zöğ, H. (2017).An analysis of the relation between teacher candidates' attitudes toward the teaching profession and teaching-learning process competencies.Pegem Ĕ̆itim ve Ögrretim Dergisi, 7(4).

Tanriseven, I. (2013). The effect of school practices on teacher candidates' sense of efficacy relating to use of drama in education. Educational Sciences: Theory and Practice, 13(1), 402-412.

Tavşancıl, E. (2002). Tutumların ölçülmesi ve spss ile veri analizi. Ankara, Nobel Publishing.

Toivanena, T., Antikainena, L., \& Ruismäkia, H. (2012). Design learning perceptions of factors determining the success or failure of drama lessons. Procedia - Social and Behavioral Sciences 45, 555 - 565.

Ulaş, H. A., Sevim, O., \& Tan, E. (2012). Attitudes of pre-service teachers of Turkish language toward creative drama course. Procedia-Social and Behavioral Science, 31, 362-368. 